Sains Malaysiana 48(8)(2019): 1575-1581

http://dx.doi.org/10.17576/jsm-2019-4808-02

\title{
Dependency of Biological Contaminants on Temperature and Relative Humidity within Praying Halls of Mosques
}

(Pergantungan Pencemaran Biologi pada Suhu dan Kelembapan di dalam Ruang Solat Masjid)

\author{
NUR BAITUl IZATI RASLI, NOR AZAM RAMLI, MOHD RODZI ISMAIL* \& SYABIHA SHITH
}

\begin{abstract}
The widespread use of Air Conditioning Split Units (ACSU) to cool the air inside mosques may pose potential adverse health effects, secondary to exposure to biological contaminants. To address this issue, the dependencies of biological contaminants (bacteria and fungi) on temperature $(T)$ and relative humidity $(R H)$ of the 'mosques' indoor air were evaluated. A total of 25 mosques were investigated during the periods in which their respective congregators were performing Zohor or Friday, and Asar prayers. The recorded average indoor bacteria and fungi concentrations were $382.6 \pm 143.9 \mathrm{cful}$ $\mathrm{m}^{3}$ and $229.4 \pm 165.5 \mathrm{cfu} / \mathrm{m}^{3}$, respectively. However, the study found that masses of bacteria aerosol within the indoors of certain mosques (10 out of 17 ACSU mosques and 1 out of 8 non-ACSU mosques) exceeded the limit recommended by Malaysian standard for indoor air quality $\left(500 \mathrm{cfu} / \mathrm{m}^{3}\right)$. Meanwhile, the results of regression analyses suggested that $T$ and RH of the indoor air have high influence on airborne bacteria and fungi. The variations in bacteria concentrations due to the influence of $T$ and $R H$ in ACSU mosques ( $T=92.3 \%$; RH=90.3\%) were higher than in non-ACSU mosques ( $T=$ $82.75 \%$; $R H=81.7 \%)$ whereas the variations in fungi concentrations in non-ACSU mosques $(T=70.45 \% ; R H=71.45 \%)$ were higher than in ACSU mosques $(T=66.05 \% ; R H=60.7 \%)$. This research shows that the growth of bacteria and fungi within the prayer halls of mosques in Malaysia is very much dependent on its indoor $T$ and RH.
\end{abstract}

Keywords: Biological contaminants; indoor air; mosque; relative humidity; temperature

ABSTRAK

Penggunaan meluas Penyaman Udara Unit Pisah (ACSU) untuk menyejukkan udara di dalam masjid boleh menimbulkan potensi kesan kesihatan yang buruk, membawa pendedahan kepada bahan cemar biologi. Bagi menangani isu ini, kebergantungan bahan cemar biologi (bakteria dan kulat) terhadap suhu $(T)$ dan kelembapan relatif (RH) daripada udara dalaman masjid telah dinilai. Sebanyak 25 buah masjid telah dikaji dalam tempoh para jemaah masing-masing sedang melaksanakan solat Zohor atau Jumaat, dan Asar. Purata kepekatan bakteria dan kulat di ruang dalaman yang direkodkan masing-masing adalah $382.6 \pm 143.9 \mathrm{cfu} / \mathrm{m}^{3}$ dan $229.4 \pm 165.5 \mathrm{cfu} / \mathrm{m}^{3}$. Walau bagaimanapun, kajian ini mendapati bahawa jisim aerosol bakteria di dalam ruang dalaman bangunan masjid tertentu (10 daripada 17 masjid ACSU dan 1 daripada 8 masjid bukan ACSU) melebihi had yang disyorkan oleh piawai Malaysia bagi kualiti udara dalaman $\left(500 \mathrm{cfu} / \mathrm{m}^{3}\right)$. Sementara itu, hasil daripada analisis regresi menunjukkan bahawa $T$ dan $R H$ daripada udara dalaman mempunyai pengaruh yang tinggi terhadap bakteria bawaan udara dan kulat. Variasi dalam kepekatan bakteria akibat pengaruh $T$ dan $R H$ di masjid ACSU $(T=92.3 \% ; R H=90.3 \%)$ adalah lebih tinggi daripada di masjid bukan ACSU $(T=82.75 \% ; R H=81.7 \%)$ manakala variasi dalam kepekatan kulat di masjid bukan ACSU $(T=70.45 \%$; $R H=71.45 \%)$ adalah lebih tinggi daripada di masjid ACSU $(T=66.05 \% ; R H=60.7 \%)$. Kajian ini menunjukkan bahawa pertumbuhan bakteria dan kulat di dalam dewan solat masjid di Malaysia sangat bergantung kepada T dan RH bagi udara dalamannya.

Kata kunci: Bahan cemar biologi; kelembapan relatif; masjid; suhu; udara dalaman

\section{INTRODUCTION}

Many studies have been carried out on biological contaminants (bacteria and fungi) levels in different building environments, such as mosques, schools, offices, restaurants and industrial processes (Alananbeh et al. 2017; Backman et al. 2014; Bornehag et al. 2001; Hameed \& Habeeballah, 2013; Kousar et al. 2013; Mashat 2015; Meklin et al. 2002; Mendell et al. 2014; Nahar \& Mahyudin 2018). The results showed that in indoor environments, one of the strongest and most consistent risk factors for health problems, which include sick building syndrome (SBS), asthma and allergies and respiratory illnesses, is moisture problems in buildings, known broadly as 'dampness'. Dampness may be caused by the use of multiple Air Conditioning Split Units (ACSU) for reducing the indoor temperature to reach comfort. Due to this, a number of chemical and biological agents have been suspected to be the causal agents in the relationship between atopic diseases and dampness in buildings. Therefore, the Malaysia's Industry 
Code of Practice (ICOP) has recommended the acceptable guideline limit for biological contaminants (bacteria and fungi) to provide a safer indoor environment for building occupants. The guideline limits for bacteria and fungi are $500 \mathrm{cfu} / \mathrm{m}^{3}$ and $1000 \mathrm{cfu} / \mathrm{m}^{3}$, respectively (DOSH 2010).

As a tropical climate country, low ventilation rates combined with high outdoor pollutants may affect the indoor air quality (IAQ) of buildings in Malaysia. Furthermore, high humidity and high temperature conditions increase the risk of thermal discomfort and moisture problems indoors (Hamimah et al. 2010). Several previous IAQ studies in Malaysia reported that IAQ, thermal comfort and SBS have become common issues in buildings in Malaysia (Kamaruzzaman \& Razak 2011; Makhtar et al. 2010; Mustapha et al. 2008; Norhidayah et al. 2013; Sulaiman et al. 2005). Mosques, which are places of worship for Muslims, have unique functional requirements and operational characteristics. Worshippers in mosques need to feel comfortable and calm during daily and weekly prayers and leave with a feeling of tranquility and peace.

Therefore, a comprehensive investigation of biological contaminant levels in mosque buildings across representative and typical mosque buildings in Malaysia is needed. Moreover, information on the effects of ventilation strategies in mosque buildings in terms of ventilation system and biological contaminant levels is lacking. The purpose of this research was to investigate the dependency of bacteria and fungi on temperature (T) and relative humidity ( $\mathrm{RH})$ in the mosque building environments within different ventilation systems in the tropical climate conditions.

\section{MATERIALS AND METHODS}

\section{MONITORING AND SAMPLING LOCATION}

Monitoring and sampling were conducted at 24 mosques in the South Seberang Perai District and one (1) mosque in the Northeast District, of Pulau Pinang, Malaysia. The 25 mosques represented the qariah/jamek mosques of Malaysia (MS 2014). Monitoring and sampling were carried out at two different categories of mosques based on their active ventilation systems, namely ACSU (17 mosques) and non-ACSU (8 mosques).

\section{PHYSICAL PARAMETERS MONITORING METHOD}

Monitoring of the physical parameters i.e. temperature $(\mathrm{T})$, relative humidity $(\mathrm{RH})$ and air movement (AM) were conducted before Zohor/Friday prayer (1200 - $1300 \mathrm{~h}$ ), during Zohor/Friday prayer (1300 - 1400/1430 h), between Zohor/Friday prayer (1400/1430 - $1600 \mathrm{~h}$ ) and during Asar prayer (1600 - 1700/1730 h). To account for ventilation approaches, two different types of ventilation, passive and active, were considered in this study. Before and after the prayer sessions, all active ventilation equipment, such as fans and ACSU, were not in operation as there were no worshippers inside the prayer halls; whereas during the prayer sessions, fans and ACSU were operated due to the presence of worshippers. The instrument (Indoor Air Quality probe (IQ-610)) was placed on a tripod, and monitoring was conducted at $\sim 1.3 \mathrm{~m}$ above the floor with one (1) min intervals.

\section{SAMPLING METHOD FOR BIOLOGICAL CONTAMINANTS}

Biological contaminants (bacteria and fungi) were sampled in two conditions, before, and after vacuuming the carpets of $(3 \mathrm{~m} \times 3 \mathrm{~m})$ square area, as to force the uplifting of biological contaminants into the air. A Microbial Air Sampler (100 Model Eco Pump, Merck, Darmstadt, Germany) was used for all sample collections, with a flow rate of $100 \mathrm{~L} / \mathrm{min}$ and a sampling time of $5 \mathrm{~min}$ to avoid the collection of unaccountable microorganisms. A total of four (4) samples were collected for each mosque, at the height of $\sim 0.6 \mathrm{~m}$ above the floor. The airborne microorganisms were targeted one after another using a $20 \mathrm{~mL}$ nutrient plate (tryptic soy agar, TSA) for bacteria, and Sabouraud dextrose agar with chloramphenicol (SDAC) for fungi, which was coupled inside the stage sampler. The Petri plates, with duplicates, for both bacteria and fungi contaminants were prepared. The biological sampling was conducted according to the National Institute for Occupational Safety and Health (NIOSH) 0800 method - Bioaerosol Sampling (Indoor Air) (NIOSH 1998). When changing the collection plates, the stage hole was sterilised with $70 \%$ ethanol solution to prevent cross-contamination. Upon completion of sample collections, the agar plates were transported to the laboratory and incubated at $35 \pm 1{ }^{\circ} \mathrm{C}$ for $24 \mathrm{~h}$ for bacteria and at $25 \pm 1{ }^{\circ} \mathrm{C}$ for 5 days for fungi. Colony forming units per cubic meter of air sampled $\left(\mathrm{cfu} / \mathrm{m}^{3}\right)$ are calculated as in (1) (DM 2001).

$$
\begin{aligned}
& \text { Total bacterial or fungal } \\
& \text { counts }\left(\mathrm{cfu} / \mathrm{m}^{3}\right)
\end{aligned}=\frac{\text { Bacteria or fungi counts }(\mathrm{cfu})}{\text { Volume of air sampled }\left(\mathrm{m}^{3}\right)}
$$

\section{LINEAR REGRESSION ANALYSIS}

The strength of linear association between two variables is quantified by $\mathrm{R}^{2}$, which represents the fraction of the variation in one variable that may be explained by the other variable. $\mathrm{R}^{2}$ can be calculated using (2) (Junninen et al. 2004).

$$
R^{2}=\frac{\sum\left(Y_{i}-\bar{Y}\right)\left(X_{i}-\bar{X}\right)}{n S_{Y} S_{X}}
$$

where $n$ is the number of data; $X_{i}$ is the total bacterial count/total fungal count; $Y_{i}$ is the T/RH; $\bar{X}$ is the mean of total bacterial count/total fungal count; $\bar{Y}$ is the mean of $\mathrm{T} / \mathrm{RH} ; S_{X}$ is the standard deviation of total bacterial count/ total fungal count; and $S_{Y}$ is the standard deviation of $\mathrm{T} /$ $\mathrm{RH}$. If the $\mathrm{R}^{2}$ value is near 1 , the relationship is almost perfectly associated with each other, whereas if the value 
is close to 0 , no association between the variables exists (Mukaka 2012).

\section{RESULTS AND DISCUSSION}

\section{DESCRIPTIVE STATISTIC}

Table 1 provides the details of physical parameters ( $T$, $\mathrm{RH}$ and $\mathrm{AM}$ ) in ACSU and non-ACSU mosques during Zohor-Asar and Friday-Asar prayers. Geographically, Malaysia is in a tropical zone, which has relatively high air temperature, abundant rainfall and high humidity throughout the year. The mean $\mathrm{T}$ for all prayer times at ACSU mosques was $26.06 \pm 0.90^{\circ} \mathrm{C}$ to $35.63 \pm 0.89^{\circ} \mathrm{C}$ and $31.08 \pm 0.52^{\circ} \mathrm{C}$ to $33.23 \pm 0.72^{\circ} \mathrm{C}$ in non-ACSU mosques. In both categories of buildings, the $\mathrm{T}$ was higher than the acceptable limit range provided by the ICOP, which is $23^{\circ} \mathrm{C}$ to $26^{\circ} \mathrm{C}$. Zohor/Friday and Asar are performed during the hottest times of the day, which is between afternoon and evening. During these hours, active ventilation systems (ACSU and fans) are preferred to 'cool down' the area inside the mosques.

Natural ventilation may help improving the thermal comfort inside mosque buildings because the air movement in and out of these buildings can decrease the $\mathrm{T}$ within the space (Noman et al. 2016). Unfortunately, we observed that the sliding windows (majority of the mosques have this window panel type) were only opened during the prayer sessions due to security reason. The mean RH for all prayer times at ACSU mosques was $51.36 \pm 2.32 \%$ to $72.27 \pm 3.19 \%$ and $56.41 \pm 3.46 \%$ to $69.66 \pm 1.43 \%$ at non-ACSU mosques. RH which was $40 \%$ to $70 \%$ for non-ACSU mosques, was in the range of ICOP's acceptable limit. AM at ACSU mosques was $0.03 \pm 0.02 \mathrm{~m} / \mathrm{s}$ to $0.38 \pm 1.47 \mathrm{~m} / \mathrm{s}$ and $0.06 \pm 0.08 \mathrm{~m} / \mathrm{s}$ to $0.65 \pm 0.29 \mathrm{~m} / \mathrm{s}$ at non-ACSU mosques

The results showed that the average indoor bacteria $\left(382.6 \pm 143.9 \mathrm{cfu} / \mathrm{m}^{3}\right)$ and fungi $\left(229.4 \pm 165.5 \mathrm{cfu} / \mathrm{m}^{3}\right) \mathrm{did}$ not exceed the respective acceptable limits of $500 \mathrm{cfu} /$ $\mathrm{m}^{3}$ and $1000 \mathrm{cfu} / \mathrm{m}^{3}$ by ICOP (DOSH 2010). However, the study found that bacteria concentrations in 10 out of 17 ACSU mosques and in 1 out of 8 non-ACSU mosques had exceeded the limits. Meanwhile, the fungi concentrations did not exceed the permissible limit in both ACSU and non-ACSU mosques. Conversely, Zock et al. (2002) found that dampness had caused indoor mold growth in houses, which eventually had an adverse effect on adult asthma.

\section{REGRESSION ANALYSIS}

Regression analyses of air $\mathrm{T}$ during sampling and biological contaminants (bacteria and fungi) for ACSU and non-ACSU mosques (before and after vacuum) were conducted to determine the dependency of biological contaminants on indoor air T, as shown in Figure 1(a) to 1(d). The $\mathrm{R}^{2}$ values of $\mathrm{T}$ with total bacterial count before and after carpet vacuuming for ACSU mosques were 0.924 and 0.922 , respectively, whereas the values were
0.866 and 0.789 for non-ACSU mosques, respectively. Meanwhile, $\mathrm{R}^{2}$ values of $\mathrm{T}$ with total fungal count before and after carpet vacuuming in ACSU mosques were 0.653 and 0.668 , respectively, whereas the values for non-ACSU mosques were 0.730 and 0.679 , respectively. These indicate that on average, $92.3 \%$ (bacteria in ACSU mosques), $82.75 \%$ (bacteria in non-ACSU mosques), $66.05 \%$ (fungi in ACSU mosques) and $70.45 \%$ (fungi in non-ACSU mosques) of the variations in biological contaminants were influenced by $\mathrm{T}$.

The plots illustrated a strong positive relationship between T and bacteria for ACSU and non-ACSU mosques. However, a strong relationship between $\mathrm{T}$ and fungi was only found in non-ACSU mosques, whereas the relationship was moderate for ACSU mosques. Therefore, we can justify that $\mathrm{T}$ has a significant effect towards bacteria and fungi growth. $\mathrm{T}$ is a significant variation factor for airborne bacteria, and it governs the rate of water vapour change and the exchange of heat between the surface and environment (Mouli et al. 2005). Furthermore, T affects the viability of airborne bacteria through the evaporation of their cellular water. In addition, although biological contaminants can reproduce within different $\mathrm{T}$ ranges, the typical span for bacteria ranges between $35^{\circ} \mathrm{C}$ and $40^{\circ} \mathrm{C}$, and $25^{\circ} \mathrm{C}$ to $30^{\circ} \mathrm{C}$ for fungi (Ross \& Nichols 2014).

The relationships between $\mathrm{RH}$ and biological contaminants (bacteria and fungi) are shown in Figure 2(a) to 2(d). The $R^{2}$ values between $R H$ and bacteria before and after carpet vacuuming were 0.926 and 0.880 , respectively, for ACSU mosques, whereas for non-ACSU mosques, the $\mathrm{R}^{2}$ values were 0.872 and 0.762 , respectively. The $\mathrm{R}^{2}$ values between $\mathrm{RH}$ and fungi before and after carpet vacuuming were 0.595 and 0.619 , respectively, for ACSU mosques, and 0.732 and 0.697 for non-ACSU mosques, respectively.

Therefore, on average, $90.3 \%$ (bacteria in ACSU mosques), $81.7 \%$ (bacteria in non-ACSU mosques), $60.7 \%$ (fungi in ACSU mosques) and $71.45 \%$ (fungi in non-ACSU mosques) of the variations in biological contaminants were influenced by RH. Thus, RH also has a significant factor for bacteria and fungi growths. The plots illustrated a strong positive relationship between RH and bacteria for ACSU and non-ACSU mosques; and between RH and fungi for non-ACSU mosques. Moreover, a high RH percentage may favour the viability of biological contaminants (Mouli et al. 2005). Rajasekar and Balasubramanian (2011) found a similar result, wherein the indoor fungal growth was positively correlated with RH.

The results of this research show that in ACSU mosques, the growth of bacteria and fungi were high at $\mathrm{T}$ and $\mathrm{RH}$ in the range between $26.06 \pm 0.90^{\circ} \mathrm{C}$ to $35.63 \pm 0.89^{\circ} \mathrm{C}$ and $51.36 \pm 2.32 \%$ to $72.27 \pm 3.19 \%$, respectively, while in non-ACSU mosques, their growth were found to be high at $\mathrm{T}$ and $\mathrm{RH}$ in the range between $31.08 \pm 0.52^{\circ} \mathrm{C}$ and $33.23 \pm 0.72^{\circ} \mathrm{C}$ and $56.41 \pm 3.46 \%$ and $69.66 \pm 1.43 \%$, respectively. 
TABLE 1. Details of physical parameters (T, RH, AM and total counts of bacteria and fungi) of ACSU and Non-ACSU mosques

\begin{tabular}{|c|c|c|c|c|c|c|c|c|}
\hline \multirow{2}{*}{$\begin{array}{l}\text { Ventilation } \\
\text { system }\end{array}$} & \multirow[t]{2}{*}{ Coordinate } & \multirow[t]{2}{*}{$\mathrm{T}\left({ }^{\circ} \mathrm{C}\right)$} & \multirow[t]{2}{*}{ RH (\%) } & \multirow[t]{2}{*}{$\mathrm{AM}(\mathrm{m} / \mathrm{s})$} & \multicolumn{2}{|c|}{$\begin{array}{l}\text { Total bacterial counts } \\
\left(\mathrm{cfu} / \mathrm{m}^{3}\right)\end{array}$} & \multicolumn{2}{|c|}{$\begin{array}{l}\text { Total fungal counts } \\
\left(\mathrm{cfu} / \mathrm{m}^{3}\right)\end{array}$} \\
\hline & & & & & $\mathrm{BV}$ & $\mathrm{AV}$ & $\mathrm{BV}$ & $\mathrm{AV}$ \\
\hline \multirow{19}{*}{ 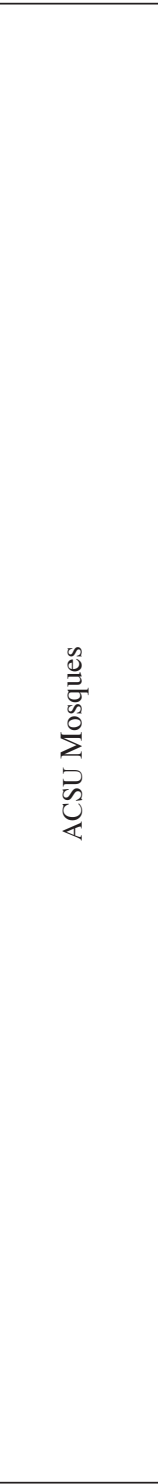 } & \multicolumn{8}{|c|}{ Zohor-Asar } \\
\hline & $\begin{array}{c}\text { N5.162445, } \\
\text { E100.515366 }\end{array}$ & $29.03 \pm 1.14$ & $59.65 \pm 1.78$ & $0.10 \pm 0.49$ & $526 *$ & 470 & 194 & 212 \\
\hline & $\begin{array}{l}\text { N5.353761, } \\
\text { E100.301634 }\end{array}$ & $26.06 \pm 0.90$ & $66.72 \pm 2.05$ & $0.03 \pm 0.02$ & 492 & 384 & 64 & 108 \\
\hline & $\begin{array}{l}\text { N5.132205, } \\
\text { E100.479464 }\end{array}$ & $29.73 \pm 1.37$ & $64.96 \pm 1.03$ & $0.18 \pm 0.60$ & 344 & 330 & 144 & 208 \\
\hline & $\begin{array}{l}\text { N5.225988, } \\
\text { E100.495166 }\end{array}$ & $29.53 \pm 1.65$ & $66.90 \pm 2.26$ & $0.32 \pm 0.99$ & 330 & 188 & 164 & 52 \\
\hline & $\begin{array}{l}\text { N5.127116, } \\
\text { E100.443831 }\end{array}$ & $31.64 \pm 1.74$ & $63.57 \pm 1.89$ & $0.17 \pm 0.68$ & $660 *$ & 430 & 382 & 508 \\
\hline & $\begin{array}{l}\text { N5.144331, } \\
\text { E100.465058 }\end{array}$ & $28.80 \pm 2.96$ & $62.48 \pm 1.60$ & $0.22 \pm 0.59$ & 414 & 300 & 72 & 118 \\
\hline & $\begin{array}{l}\text { N5.146839, } \\
\text { E100.450196 }\end{array}$ & $29.59 \pm 1.39$ & $52.98 \pm 3.14$ & $0.19 \pm 0.68$ & 320 & 272 & 70 & 72 \\
\hline & $\begin{array}{l}\text { N5.152006, } \\
\text { E100.465278 }\end{array}$ & $31.74 \pm 1.40$ & $53.83 \pm 1.84$ & $0.06 \pm 0.41$ & 418 & $620 *$ & 60 & 50 \\
\hline & $\begin{array}{l}\text { N5.197372, } \\
\text { E100.468805 }\end{array}$ & $31.86 \pm 1.52$ & $58.28 \pm 2.57$ & $0.10 \pm 0.36$ & 410 & $610^{*}$ & 94 & 62 \\
\hline & $\begin{array}{l}\text { N5.282590, } \\
\text { E100.475739 }\end{array}$ & $27.49 \pm 2.73$ & $64.08 \pm 1.42$ & $0.06 \pm 0.05$ & $514 *$ & $518 *$ & 132 & 158 \\
\hline & $\begin{array}{l}\text { N5.146025, } \\
\text { E100.408756 }\end{array}$ & $31.96 \pm 1.07$ & $65.00 \pm 3.48$ & $0.10 \pm 0.09$ & 424 & 458 & 76 & 100 \\
\hline & $\begin{array}{l}\text { N5.124312, } \\
\text { E100.418896 }\end{array}$ & $32.99 \pm 0.83$ & $56.73 \pm 4.05$ & $0.18 \pm 0.17$ & $536 *$ & 482 & 534 & 432 \\
\hline & $\begin{array}{l}\text { N5.209307, } \\
\text { E100.527626 }\end{array}$ & $27.95 \pm 1.86$ & $72.27 \pm 3.19$ & $0.03 \pm 0.04$ & $576^{*}$ & 396 & 288 & 314 \\
\hline & $\begin{array}{c}\text { N5.276925, } \\
\text { E100.517778 }\end{array}$ & $32.86 \pm 0.56$ & $61.84 \pm 1.99$ & $0.32 \pm 0.75$ & 396 & $528^{*}$ & 288 & 334 \\
\hline & $\begin{array}{c}\text { N5.274137, } \\
\text { E100.444558 }\end{array}$ & $35.63 \pm 0.89$ & $51.36 \pm 2.32$ & $0.09 \pm 0.10$ & 166 & 162 & 388 & 336 \\
\hline & \multicolumn{8}{|c|}{ Friday-Asar } \\
\hline & $\begin{array}{l}\text { N5.284348, } \\
\text { E100.495882 }\end{array}$ & $29.39 \pm 1.69$ & $60.56 \pm 1.32$ & $0.26 \pm 0.16$ & $512 *$ & 490 & 198 & 210 \\
\hline & $\begin{array}{c}\text { N5.275097, } \\
\text { E100.427235 }\end{array}$ & $32.97 \pm 1.04$ & $60.54 \pm 5.07$ & $0.38 \pm 1.47$ & 450 & $552^{*}$ & 660 & 658 \\
\hline \multirow{10}{*}{ 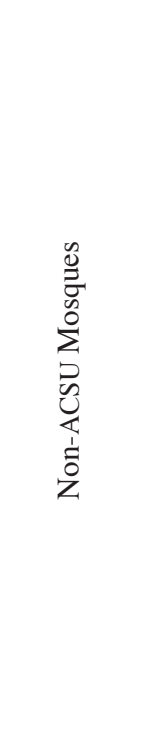 } & \multicolumn{8}{|c|}{ Zohor-Asar } \\
\hline & $\begin{array}{l}\text { N5.144766, } \\
\text { E100.494040 }\end{array}$ & $31.08 \pm 0.52$ & $69.60 \pm 4.63$ & $0.21 \pm 0.94$ & 378 & 94 & 144 & 134 \\
\hline & $\begin{array}{l}\text { N5.174619, } \\
\text { E100.541203 }\end{array}$ & $33.23 \pm 0.72$ & $56.41 \pm 3.46$ & $0.06 \pm 0.08$ & 484 & 132 & 300 & 216 \\
\hline & $\begin{array}{c}\text { N5.284583, } \\
\text { E100.509856 }\end{array}$ & $31.28 \pm 0.88$ & $63.40 \pm 2.80$ & $0.06 \pm 0.07$ & 312 & 224 & 306 & 240 \\
\hline & \multicolumn{8}{|c|}{ Friday-Asar } \\
\hline & $\begin{array}{l}\text { N5.148894, } \\
\text { E100.487500 }\end{array}$ & $31.58 \pm 0.47$ & $68.05 \pm 3.18$ & $0.24 \pm 0.21$ & $502 *$ & 320 & 318 & 222 \\
\hline & $\begin{array}{l}\text { N5.168175, } \\
\text { E100.477498 }\end{array}$ & $32.27 \pm 0.69$ & $61.73 \pm 2.30$ & $0.28 \pm 0.11$ & 370 & 390 & 200 & 76 \\
\hline & $\begin{array}{l}\text { N5.167577, } \\
\text { E100.493589 }\end{array}$ & $32.80 \pm 0.54$ & $57.38 \pm 1.79$ & $0.36 \pm 0.78$ & 360 & 260 & 198 & 178 \\
\hline & $\begin{array}{l}\text { N5.148779, } \\
\text { E100.420434 }\end{array}$ & $31.67 \pm 0.34$ & $69.66 \pm 1.43$ & $0.65 \pm 0.29$ & 67 & 91 & 50 & 70 \\
\hline & $\begin{array}{l}\text { N5.221623, } \\
\text { E100.497009 }\end{array}$ & $31.71 \pm 0.95$ & $66.80 \pm 7.04$ & $0.23 \pm 0.13$ & 272 & 196 & 576 & 502 \\
\hline
\end{tabular}

Indicator: * - Exceeded ICOP limit; ACSU - Air Conditioning Split Unit; Non-ACSU - Non-Air Conditioning Split Unit, BV - Before Vacuum; AV - After Vacuum; T Temperature; RH- Relative Humidity; AM - Air Movement 

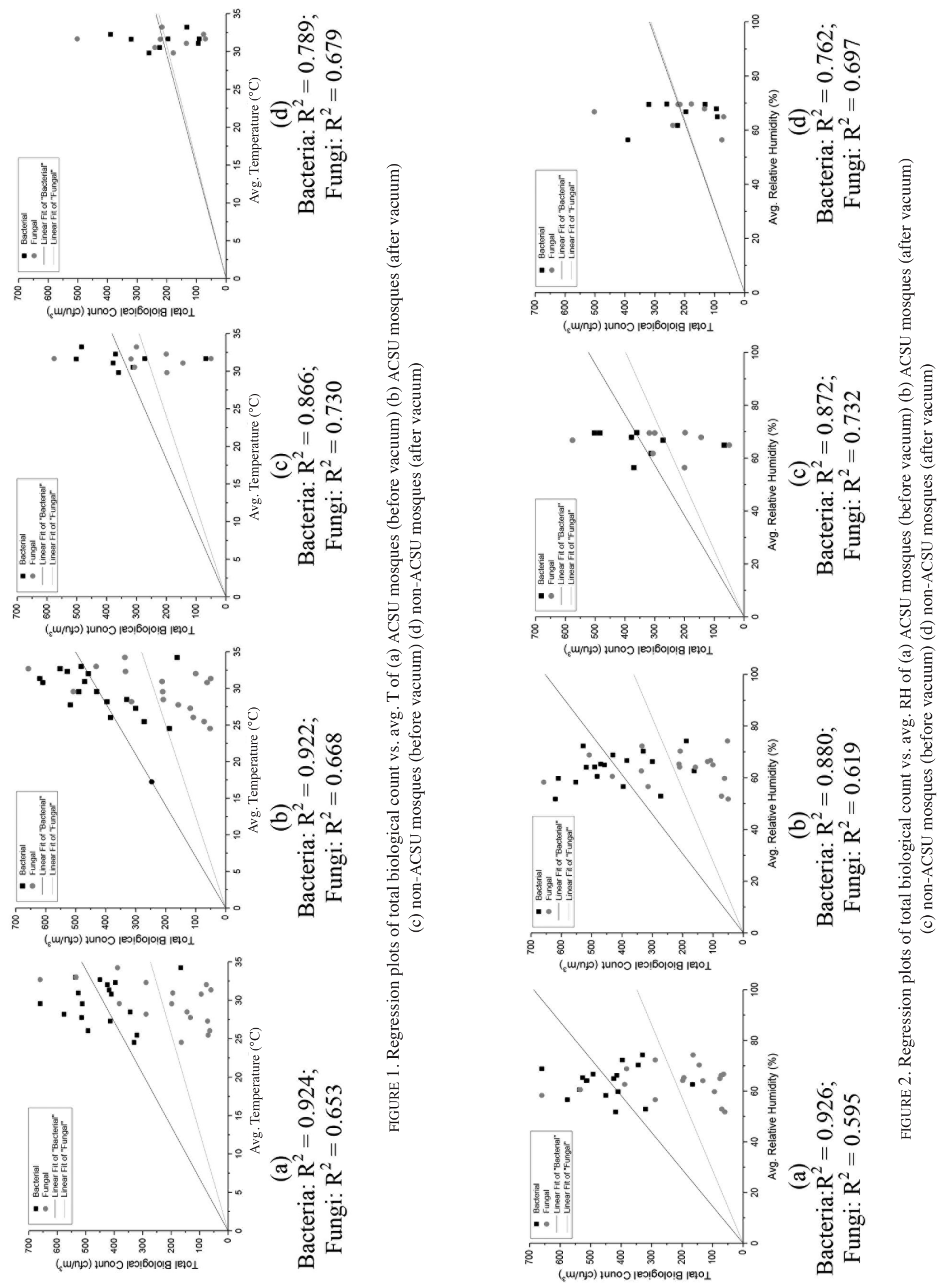


\section{CONCLUSION}

Total bacteria and fungi were sampled from the air within prayer halls of the studied mosques and then cultured to determine their growths, in which the results suggested several exceedances of total bacterial count above the 500 $\mathrm{cfu} / \mathrm{m}^{3}$ limit as recommended by ICOP. High growth of bacteria and fungi were found in the ACSU mosques at $\mathrm{T}$ and $\mathrm{RH}$ in the range between $28.74 \pm 1.08^{\circ} \mathrm{C}$ and $31.93 \pm 0.20^{\circ} \mathrm{C}$ and $61.85 \pm 0.74 \%$ and $64.76 \pm 1.39 \%$, respectively. As for the non-ACSU mosques, the growth bacteria and fungi were high at respective $\mathrm{T}$ and $\mathrm{RH}$ in the range between $31.12 \pm 0.25^{\circ} \mathrm{C}$ and $32.13 \pm 0.40^{\circ} \mathrm{C}$ and $62.01 \pm 1.58 \%$ and $70.57 \pm 0.72 \%$. The variations in bacteria concentrations due to the influence of $\mathrm{T}$ and RH in ACSU mosques ( $\mathrm{T}=$ $92.3 \%$; $\mathrm{RH}=90.3 \%$ ) were higher than the ones in non-ACSU mosques $(\mathrm{T}=82.75 \%$; $\mathrm{RH}=81.7 \%)$, whereas the variations in fungi concentrations in non-ACSU mosques ( $\mathrm{T}=70.45 \%$; $\mathrm{RH}=71.45 \%$ ) were higher than the variations in ACSU mosques $(\mathrm{T}=66.05 \%$; $\mathrm{RH}=60.7 \%)$. This research shows that the growth of bacteria and fungi within the prayer halls of mosques in Malaysia is very much dependent on its indoor T and RH. It can be indicated that the tropical hot and humid climate of Malaysia provides a suitable environment for the growth of bacteria and fungi, therefore, the indoor air within mosques should be maintained at an acceptable quality to protect the worshippers from being exposed to health risks. The findings from this study could act as a guide for relevant authorities to prepare an operations and maintenance (O\&M) standard for mosques in term of controlling the $\mathrm{T}$ and $\mathrm{RH}$; and managing the carpet cleaning within the main prayer halls of mosques as to eliminate the bacterial and fungal growth for a sustainable life of worshippers.

\section{ACKNOWLEDGEMENTS}

This research was supported by the Ministry of Science Technology and Innovation, Malaysia under SCIENCEFUND 305/PAWAM/6013607 (06-01-05-SF0766) grant.

\section{REFERENCES}

Alananbeh, K.M., Boquellah, N., Al Kaff, N. \& Al Ahmadi, M. 2017. Evaluation of aerial microbial pollutants in Al-Haram Al-Nabawi during pilgrimage of 2013. Saudi Journal of Biological Sciences 24: 217-225.

Backman, H., Hedman, L., Jansson, S.A., Lindberg, A., Lundbäck, B. \& Rönmark, E. 2014. Prevalence trends in respiratory symptoms and asthma in relation to smokingtwo cross-sectional studies ten years apart among adults in Northern Sweden. World Allergy Organization Journal 7(1): $1-10$.

Bornehag, C.G., Blomquist, G., Gyntelberg, F., Jarvholm, B., Malmberg, P., Nordvall, L. \& Sundell, J. 2001. Dampness in buildings and health. Indoor Air 11(2): 72-86.

DM. 2001. Department of Microbiology. Mount Sinai Hospital. Procedure Manual Toronto Medical Laboratories. Sterility Testing Manual: Air Sampling. Canada. 17-18. https://eportal. mountsinai.ca/Microbiology//manual/ster/mi_ster.pdf.
DOSH. 2010.Department of Occupational Safety and Health. Industry code of practice on indoor air quality. Malaysia: Ministry of Human Resources, pp. 1-39.

Hameed, A.A. \& Habeeballah, T. 2013. Air microbial contamination at the holy mosque, Makkah, Saudi Arabia. Current World Environment 8(2): 179-187.

Hamimah, S., Baba, D. \& Abd. Mutalib, L. 2010. Indoor air quality issues for non-industrial work place. International Journal of Research and Review in Applied Sciences 5(3): 235-244.

Junninen, H., Niska, H., Tuppurainen, K., Ruuskanen, J. \& Kolehmainen, M. 2004. Methods for imputation of missing values in air quality data sets. Atmospheric Environment 38(18): 2895-2907.

Kamaruzzaman, S.N. \& Razak, R.A. 2011. Measuring indoor air quality performance in Malaysian government kindergarten. Journal of Building Performance 2(1): 70-79.

Kousar, S., Mustafa. G. \& Jamil, A. 2013. Microbial xylosidases: Production and biochemical characterization. Pakistan Journal of Life and Social Science 11(2): 85-95.

Makhtar, N.K., Ismail, A.R., Jusoh, N. \& Puvanasvaran, A.P. 2010. Thermal comfort in technical school: Physical measurement approach. National Conference in Mechanical Engineering Research and Postgraduate Studies (2nd NCMER 2010). pp. 755-761.

Mashat, B. 2015. Indoor and outdoor microbial aerosols at the holy mosque: A case study. Atmospheric Pollution Research 6(6): 990-996.

Meklin, T., Reponen, T., Toivola, M., Koponen, V., Husman, T., Hyvärinen, A. \& Nevalainen, A. 2002. Size distributions of airborne microbes in moisture-damaged and reference school buildings of two construction types. Atmospheric Environment 36(39-40): 6031-6039.

Mendell, M.J., Macher, J.M. \& Kumagai, K. 2014. Indoor dampness and mold as indicators of respiratory health risks, Part 3: A synthesis of published data on indoor measured moisture and health. International Society of Indoor Air Quality and Climate (ISIAQ) Proceedings of Indoor Air 1: 727-734.

Mouli,P., Mohan, S. \& Reddy, S. 2005. Assessment of microbial (bacteria) concentrations of ambient air at semi-arid urban region: Influence of meteorological factors. Applied Ecology and Environmental Research 3(2): 139-149.

MS. 2014. Malaysian Standard. MS 2577: 2014. Architecture and asset management of masjid - Code of practice. Department of Standards Malaysia. Malaysia.

Mukaka, M. 2012. A guide to appropriate use of correlation coefficient in medical research. Malawi Medical Journal 24(3): 69-71.

Mustapha, A.A., Ayop, S.M., Ahmad, M.K. \& Ismail, F. 2008. A thermal comfort study in naturally ventilated school building in Malaysia. Built Environment Journal 5(2): 66-82.

Nahar, N. \& Mahyudin, N.A. 2018. Microbiological quality of food contact surfaces (spoons) at selected restaurants in Klang Valley, Malaysia. Sains Malaysiana 47(7): 1541-1545.

NIOSH. 1998. National Institute for Occupational Safety and Health. Bioaerosol sampling (Indoor Air) 0800: Culturable organisms bacteria, fungi, thermophilic actinomycetes, NIOSH Manual of Analytical Methods (NMAM), 4th ed. Washington, D.C.: National Institute for Occupational Safety and Health.

Noman, F.G., Kamsah, N. \& Kamar, H.M. 2016. Improvement of thermal comfort inside a mosque building. Jurnal Teknologi 78(8-5): 9-18. 
Norhidayah, A., Chia-Kuang, L., Azhar, M.K. \& Nurulwahida, S. 2013. Indoor air quality and sick building syndrome in three selected buildings. Procedia Engineering 53: 93-98.

Rajasekar, A. \& Balasubramanian, R. 2011. Assessment of airborne bacteria and fungi in food courts. Building and Environment 46(10): 2081-2087.

Ross, T. \& Nichols, D.S. 2014. Ecology of bacteria and fungi in foods: Influence of temperature. In. Encyclopedia of Food Microbiology, edited by Batt, C.A. \& Tortorello, M.L. 2nd ed. Amsterdam: Academic Press. pp. 602-609.

Sulaiman, N.,Abdullah, M. \& Chieu, P.L.P. 2005. Concentration and composition of $\mathrm{PM}_{10}$ in outdoor and indoor air in industrial area of Balakong Selangor, Malaysia. Sains Malaysiana 34(2): 43-47.

Zock, J.P., Jarvis, D., Luczynska, C., Sunyer, J. \& Burney, P. 2002. Housing characteristics, reported mold exposure, and asthma in the European community respiratory health survey. Journal of Allergy and Clinical Immunology 110(2): 285-292.

Nur Baitul Izati Rasli, Nor Azam Ramli \& Syabiha Shith

Environmental Assessment and Clean Air Research (EACAR)

School of Civil Engineering

Engineering Campus

Universiti Sains Malaysia

14300 Nibong Tebal, Pulau Pinang

Malaysia
Mohd Rodzi Ismail*

School of Housing Building and Planning

Universiti Sains Malaysia

11800 USM, Pulau Pinang

Malaysia

*Corresponding author; email: rodzi@usm.my

Received: 20 January 2019

Accepted: 12 May 2019 